\title{
PERFORMA KOMUNIKATIF PEMERINTAH DALAM MELAKUKAN SOSIALISASI KEBIJAKAN PUBLIK AMNESTI PAJAK
}

\author{
Mercy Lona Darwaty Ryndang Sriganda \\ Universitas Indraprasta PGRI, Jakarta \\ Email: mercy.lona@unindra.ac.id
}

\begin{abstract}
Important socialization is carried out by the government in every launch of a public policy including the socialization of tax amnesty policies. The tax amnesty socialization was carried out by government institutions namely the Directorate of Tax Dissemination, Services and Public Relations of the Directorate General of Taxes (Dit. P2Humas Ditjen Pajak). This topic was chosen because the tax amnesty program became a phenomenon, socialization took place in a short period of time around nine months along with the implementation of the policy. The formulation of the problem in this research is to find out how the communicative performance of the government in disseminating tax amnesty public policies. The aim to be achieved is to analyze and find out the communicative performance of the government in disseminating public policies on tax amnesty. The concept used in this research is communicative performance which is a derivative of organizational culture theory. The research method used is a qualitative approach with a case study method. The results showed that the socialization carried out by the government could increase public knowledge about tax amnesty public policies but could not improve tax amnesty results. Suggestions for future research are regarding the relationship of socialization with the level of community compliance and adherence to a public policy
\end{abstract}

Keywords: Tax Amnesty, Socialization, Communicative Performance

\begin{abstract}
ABSTRAK
Sosialisasi penting dilakukan oleh pemerintah dalam setiap peluncuran sebuah kebijakan publik termasuk sosialisasi kebijakan publik amnesti pajak. Sosialisasi amnesti pajak dilakukan oleh institusi pemerintah yaitu Direktorat Penyuluhan, Pelayanan dan Hubungan Masyarakat Direktorat Jenderal Pajak (Dit. P2Humas Ditjen Pajak). Topik ini dipilih karena program amnesti pajak menjadi fenomena, sosialisasi berjalan dalam kurun waktu singkat sekitar sembilan bulan bersamaan dengan pelaksanaan kebijakannya. Rumusan masalah pada penelitian ini yaitu untuk mengetahui bagaimana performa komunikatif pemerintah dalam melakukan sosialisasi kebijakan publik amnesti pajak. Tujuan yang ingin dicapai adalah untuk mengetahui performa komunikatif pemerintah dalam melakukan sosialisasi kebijakan publik amnesti pajak. Konsep yang digunakan dalam penelitian ini adalah performa komunikatif yang merupakan turunan dari teori budaya organisasi. Metode penelitian yang dipakai adalah pendekatan kualitatif dengan metode studi kasus.
\end{abstract}


Hasil penelitian menunjukkan bahwa sosialisasi yang dilakukan pemerintah dapat meningkatkan pengetahuan masyarakat tentang kebijakan publik amnesti pajak namun tidak dapat meningkatkan hasil amnesti pajak. Saran untuk penelitian mendatang adalah mengenai hubungan sosialisasi dengan tingkat kepatuhan dan ketaatan masyarakat terhadap suatu kebijakan publik.

Kata Kunci: Amnesti Pajak, Sosialisasi, Performa Komunikatif

\section{PENDAHULUAN}

Kebijakan publik pengampunan pajak tax amnesty atau amnesti pajak diimplementasikan mulai tanggal 1 Juli 2016, pelaksanaannya berakhir pada tanggal tanggal 31 Maret 2017. Pelaksanaan kebijakan amnesti pajak selama tiga periode sudah berjalan dengan berbagai dinamika. Dinamika itu antara lain diwarnai pro kontra, mendukung dan tidak mendukung, berpartisipasi atau tidak berpartisipasi terhadap amnesti pajak. Di tengah dinamika yang bergejolak program tax amnesty tetap dapat terlaksana sampai usai. Amnesti pajak menjadi bagian yang dijadikan solusi bagi pemerintah untuk mendorong penerimaan pajak di tahun 2016. Tujuan pelaksanaan amnesti pajak ditetapkan dengan niat mulai untuk sebesar-besarnya kepentingan negara antara lain untuk mempercepat pembangunan infrastruktur di seluruh Indonesia, merangsang naiknya nilai tukar rupiah, meningkatkan pertambahan devisa negara serta menambah pundi-pundi pemasukan penerimaan pada Anggaran Pendapatan dan Belanja Negara.

Amnesti pajak merupakan sebuah kebijakan publik pengampunan yang diberikan oleh pemerintah kepada wajib pajak. Pemerintah memberikan kebijakan publik amnesti pajak tersebut berupa pengampunan pajak yang meliputi penghapusan pajak terutang, penghapusan sanksi administrasi perpajakan serta penghapusan sanksi pidana dibidang perpajakan atas harta yang diperoleh pada tahun 2015 dan sebelumnya yang dilaporkan dalam Surat Pemberitahuan Tahunan (SPT). Adapun caranya dengan melunasi seluruh tunggakan pajak cukup dengan membayar uang tebusan yang persentasenya ditetapkan oleh pemerintah. 
Kebijakan amnesti pajak selain bertujuan untuk mendorong penerimaan negara juga memiliki tujuan yang baik untuk wajib pajak dalam konteks menyelesaikan utang pajaknya. Ada keuntungan bagi wajib pajak yang mengikuti tax amnesty yaitu mendapatkan fasilitas uang tebusan rendah disesuaikan dengan persentase yang digariskan. Wajib pajak terhindar dari denda pajak yang relatif besar serta bebas dari pemeriksaan SPT. Dengan adanya pembebasan denda terhadap utang pajak, pemerintah mengharapkan masyarakat yang disasar yakni Wajib Pajak Orang Pribadi dan Wajib Pajak Badan Usaha mau melaporkan hartanya yang belum dilaporkan, baik harta yang disimpan di dalam negeri maupun harta yang terdapat di luar negeri.

Pemerintah bersama dengan Dewan Perwakilan Rakyat (DPR) membuat payung hukum yang menaungi amnesti pajak yaitu Undang- Undang Nomor 11 Tahun 2016 tentang Pengampunan Pajak. Setelah diresmikan pemberlakuannya, pemerintah melakukan kegiatan komunikasi kebijakan kepada masyarakat Indonesia pada umumnya dan para wajib pajak khususnya dengan cara sosialisasi. Sosialisasi dilaksanakan untuk menyebarkan informasi tentang amnesti pajak sebanyakbanyaknya dan seluas-luasnya di seluruh Indonesia oleh intansi pemerintah terkait serta kerjasama antar banyak lembaga dan berbagai elemen masyarakat (Putri, 2017).

Presiden Joko Widodo sebagai kepala pemerintahan tertinggi memiliki konsentrasi yang sangat tinggi ditandai dengan komitmen dan keseriusan untuk keberhasilan kebijakan amnesti pajak. Keseriusan serta komitmen Presiden ditandai dengan mengawal program ini mulai dari perencanaan sampai implementasinya termasuk sosialisasi. Tidak semua peluncuran dan sosialisasi sebuah kebijakan publik Presiden ikut turun langsung melakukan sosialisasi tapi khusus kebijakan publik amnesti pajak Presiden ikut terjun langsung melakukan sosialisasi kepada seluruh masyarakat Indonesia.

Dalam rangka membantu pekerjaan dan tugasnya, Presiden dibantu oleh beberapa kementerian yang memiliki spesifikasi tugas pokoknya masing-masing dalam 
pemerintahan. Terkait dengan amnesti pajak, institusi pemerintah yang membantu yaitu kementerian dan unit eselon satu di bawah kementerian. Adapun kementerian yang memiliki core business atau tugas utama dalam pemerintahan mengatur dan mengurus keuangan negara adalah Kementerian Keuangan. Mengenai tugas pokok Kementerian Keuangan telah diatur melalui peraturan perundang-undangan, dalam hal ini Peraturan Presiden No. 28 Tahun 2015 tentang Kementerian Keuangan (Wijaya, 2015).

Kementerian Keuangan memiliki beberapa unit eselon satu di bawahnya dengan spesialisasi tugas pokok yang sudah ditetapkan. Unit eselon satu yang memiliki tugas berkaitan dengan perpajakan adalah Direktorat Jenderal Pajak. Di dalam tubuh Ditjen Pajak ada beberapa unit eselon dua di bawahnya yang memiliki tugas-tugas pokok sesuai bidang teknis yang menjadi spesialisasi. Unit eselon dua yang terkait dengan sosialisasi kebijakan publik amnesti pajak adalah Direktorat Penyuluhan, Pelayanan dan Hubungan Masyarakatat yang disingkat menjadi Dit. P2Humas.

Era pemerintahan Presiden Joko Widodo program kebijakan publik amnesti pajak diberlakukan. Peresmian dimulainya program dilakukan tepat pada tanggal 1 Juli 2016 bertempat di Kantor Pusat Ditjen Pajak. Selanjutnya Presiden ikut turun lapangan menyosialisasikan amnesti pajak kepada masyarakat ke berbagai kota di Indonesia. Program amnesti pajak memiliki jumlah target penerimaan yang diharapkan dapat diperoleh. Target penerimaan dari hasil amnesti pajak ditetapkan demikian besar dengan ekspektasi bahwa masyarakat yang disasar benar-benar memanfaatkan pelaksanaan kebijakan tersebut. Jumlah rupiah yang ditargetkan akan masuk ke dalam pundi-pundi negara adalah sebanyak 165 triliun (Rumata, 2017).

Pertama kali, Presiden Jokowi ikut melakukan sosialisasi amnesti pajak pada tanggal 15 Juli 2016 di kota Surabaya bertempat di Grand City (Dit. P2Humas Ditjen Pajak). Sosialisasi yang dilakukan Presiden terlihat dalam pemberitaan pada media massa bagaimana beliau safari dari kota ke kota, bertemu dengan berbagai segmentasi wajib 
pajak. Presiden ikut mendorong agar masyarakat yang disasar memiliki motivasi berpartisispasi menyukseskan dan memanfaatkan program amnesti pajak.

Selama Indonesia menikmati alam kemerdekaaan, sudah dua kali kebijakan publik amnesti Pajak dicanangkan tetapi belum ada yang berhasil pelaksanaannya. Hal ini diungkapkan oleh Presiden Joko Widodo dalam sosialisasi di Bandung pada tanggal 8 Agustus 2016. Jokowi menyebutkan amnesti pajak diluncurkan untuk pertama kalinya tahun 1964 tetapi tidak berhasil. Kegagalan disebabkan terjadinya Gerakan 30 September Partai Komunis Indonesia. Kedua pada tahun 1984 pada masa pemerintahan Soeharto tetapi tetap tidak berhasil juga. Kegagalan di masa lampau menjadi pelajaran berharga bagi pemerintah untuk memberlakukan kebijakan ini. Presiden menginginkan kebijakan amnesti pajak di era pemerintahannya berhasil itulah sebabnya Presiden turun langsung menyosialisasikan dan mengawasi. Selanjutnya, pemerintah pernah beberapa kali menerapkan kebijakan keringanan pajak yaitu sunset policy tahun 2008 .

Sunset policy adalah kebijakan pemerintah berupa penghapusan sanksi administrasi berupa bunga atas keterlamabatan pelunasan kekurangan pembayaran pajak. Program ini berlaku selama satu tahun dari tanggal 1 Januari sampai dengan 31 Desember 2008. Kebijakan sunset policy diatur dalam Ketentuan Umum dan Tata Cara Perpajakan (KUP). Terdapat dalam Pasal 37A Undang-Undang Nomor 28 Tahun 2007 tentang Perubahan Ketiga atas Undang-Undang Nomor 6 Tahun 1983. Sunset policy berbeda dengan amnesti pajak. Dalam sunset policy, kewajiban yang dihapuskan adalah sanksi denda administrasi, sementara pokok pajaknya tetap wajib dibayarkan penuh sesuai tarif yang berlaku (Ngadiman \& Huslin, 2015).

Setelah sunset policy dilaksanakan tahun 2008, menyusul pada tahun 2015 pemerintah kembali meluncurkan program kebijakan keringanan bagi wajib pajak dengan sebutan reinventing policy. Program ini ada yang menyebutnya sebagai sunset policy jilid dua. Belakangan program ini oleh pemerintah disebut dengan istilah Tahun 
Pembinaan Wajib Pajak (TPWP) 2015. Secara khusus, program ini bermaksud memberikan keringanan berupa insentif kepada Wajib Pajak. Wajib pajak yang mendapatkan insentif adalah mereka yang menyampaikan SPT pertama kalinya atau SPT pembetulan. Selain itu, pemberian insentif kepada wajib pajak atas keterlambatan pembayaran maupun keterlambatan pelaporan SPT di tahun 2015.

Tahun Pembinaan Wajib Pajak (TPWP) 2015 dicanangkan oleh Presiden Jokowi tanggal 29 April sampai dengan tanggal 31 Desember 2015. Pelaksanaannya kurang lebih selama delapan bulan. TPWP diluncurkan dengan semangat moto atau jargon "Reach the Unreachable, Touch the Untouchable". TPWP 2015 menyasar pada kelompok wajib pajak terdaftar yang telah menyampaikan SPT maupun yang belum menyampaikan SPT. Program ini juga diberikan kepada masyarakat, yang disasar secara khusus adalah orang pribadi atau badan yang belum terdaftar sebagai wajib pajak. Diharapkan masyarakar yang belum terdaftar sebagai wajib pajak berbondongbondong mendaftar untuk memanfaatkan program TPWP (Tanilasari \& Gunarso, 2017).

Dalam tabel berikut dapat dilihat program keringanan dan pemgampunan pajak yang pernah dilaksanakan di Indonesia:

Tabel 1

Program Keringanan dan Pengampunan Pajak

\begin{tabular}{|c|c|c|}
\hline Nama Program & Kurun Waktu & Pelaksanaan \\
\hline Amnesti Pajak & 1964 & Tidak berhasil \\
\hline Amnesti Pajak & 1984 & Tidak berhasil \\
\hline Sunset Policy & 1 Januari - 31 Desember & Berhasil \\
& 2008 & \\
\hline
\end{tabular}




\begin{tabular}{|c|c|c|}
\hline TPWP & $\begin{array}{c}\text { 29 April - 31 Desember } \\
2015\end{array}$ & Berhasil \\
& 2017 & Berhasil \\
\hline Amnesti Pajak & 1 Juli 2016-31 Maret & \\
& & \\
\hline
\end{tabular}

(RYNDANG SRIGANDA, 2017)

Bercermin pada kegagalan amnesti pajak pada masa lalu, serta melihat beberapa program keringanan bagi wajib pajak yang pernah dilakukan Ditjen Pajak, maka pemerintah terus melakukan perbaikan. Presiden Jokowi terus berupaya agar kebijakan publik amnesti pajak pada era pemerintahannya dapat berjalan dengan baik sesuai tujuan yang telah ditetapkan.

Dapat dicermati bahwa era pemerintahan Presiden Jokowi sudah dua program kebijakan besar dilaksanakan berkaitan dengan pajak. Pertama adalah TPWP pada tahun 2015. Program ini lahir dari semangat untuk memberikan pembinaan kepada Wajib Pajak yang belum memahami peraturan perpajakan. Kedua adalah program amnesti pajak pada tahun 2016 dilaksanakan selama sembilan bulan dibagi atas tiga periode.

\section{TINJAUAN PUSTAKA}

Penelitian ini dilakukan untuk mengetahui bagaimana performa komunikatif digambarkan saat pemerintah melakukan sosialisasi amnesti pajak, bagaimana dalam mengomunikasikan berbagai bentuk kebudayaan organisasi yang dibungkus dalam suatu format tertentu. Performa komunikatif merupakan perwujudan dari pemahaman akan perilaku manusia dalam sebuah organisasi. Pada konsep ini dibahas pembagian peran dalam organisasi. Pembagian peran merupakan sebuah kewajaran dimana akan terlihat bentuk berbagai interpretasi perilaku oleh seluruh individu yang menjadi bagian komponen organisasi. 
Performa komunikatif merupakan salah satu konsep yang merupakan turunan dari teori budaya organisasi. Performa komunikatif dalam organisasi terbagi atas lima bagian yaitu (West \& Turner, 2008):

1. Performa ritual

Seluruh performa yang secara konsisten dilakukan, terjadi secara teratur dan berulang disebut performa ritual (ritual performance). Performa ritual sendiri dapat terbagi lagi dalam beberapa ritual yaitu: Pertama, ritual personal (personal ritual) yang meliputi segala kegiatan yang dilakukan individu per individu dilakukan secara rutin. Kedua, ritual tugas (task ritual) yang meliputi ritual sehubungan dengan perilaku rutin dan konsisten berkaitan dengan pekerjaan utama atau pokok seseorang dalam organisasi. Ketiga, ritual sosial (social ritual), ritual sosial mencakup rutinitas verbal dan nonverbal yang dilakukan sesorang. Interaksi dengan orang lain sangat berkaitan dengan ritual sosial. Adapun ritual itu dilakukan dengan kegiatan konsisten, kegiatan yang berulang antar satu individu dengan individu lain dalam sebuah kelompok organisasi yang saling terkait. Keempat, ritual organisasi (organizational ritual), melingkupi cakupan kegiatan dan penyelenggaraan yang lebih luas dalam sebuah organisasi.

2. Performa Hasrat (passion performance)

Hasrat (passion) dalam performa komunikatif menggambarkan keinginan berbagi cerita atau sharing mengenai kondisi internal. Bagaimana berlangsungnya sebuah kebijakan dalam sebuah organisasi serta bagaimana hasrat dari anggota organisasi tersampaikan. Hasrat ini biasanya ditunjukkan oleh pemilik hasrat sebagai bentuk ketidakpuasan atau kritikan terhadap objek yang dianggap negatif.

3. Performa sosial (social performance)

Performa sosial dalam hal ini lebih mendeskripsikan sikap kesantunan dan kesopanan diantara anggota organisasi. Dalam mengomunikasikan keadaan dengan memakai simbol atau tanda yang telah ada dan biasa digunakan dalam sebuah organisasi. 
Communications Vol. 2 No. 2 Juli 2020

DOI:https://doi.org/10.21009/Communications.2.2.1

\section{Performa politis (political performance)}

Performa politis dalam budaya organisasi adalah mengomunikasikan performa politis. Performa politis ini sedang menjalankan kekuasaan dan kontrol dalam sebuah organisasi di mana struktur, hirarki, tingkatan jabatan, kekuasaan dan kewenangan terukur secara jelas dan tegas seperti halnya sebuah birokrasi. Untuk menjalankan fungsi kontrol atau pengawasan, koordinasi dalam sebuah sebuah organisasi maka ditugaskan anggota organisasi dengan tugas melekat padanya.

5. Performa enkulturasi (enculturation performance)

Performa enkulturasi dalam performa komunikatif ingin menggambarkan bagaimana anggota organisasi ditingkatkan pengetahuan dan keahliannya. Dengan harapan anggota yang telah ditingkatkan pengetahuannya dapat berkontribusi sesuai kompetensi dalam melakukan perannya pada organisasi. Peningkatan atau membangun kapasitas (capacity building) juga merupakan bagian penting pada performa enkulturasi.

Sosialisasi tentunya berkaitan erat dengan enkulturasi atau proses pembudayaan yang melebur dalam organisasi. Sosialisasi diperlukan untuk memindahkan pengetahuan atau transfer knowledge. Dengan kata lain sosialisasi yaitu suatu proses belajar seorang untuk mempelajari hal yang baru agar dapat mengenal dan memahami dengan sangat dalam sebuah kebaruan. Kemudian perlu dipahami siapa yang melaksanakan proses sosialisasi. Dalam sosiologi dikenal istilah agen sosialisasi (agents of socialization) yaitu pihak-pihak atau anggota organisasi yang terlibat dalam kegiatan sosialisasi. Fuller dan Jacobs mengidentifikasi atau membaginya menjadi empat agen sosialisasi utama yaitu keluarga, kelompok bermain, media massa dan sistem pendidikan (Kamanto, 2004). Sosialisasi bisa berupa penyuluhan atau pemberian informasi yang dilakukan baik secara langsung maupun tidak langsung, dapat melalui tatap muka maupun berbagai media pendukung lainnya media cetak, media elektronik, media luar ruang, media internet, media sosial dan lainnya. 
Communications Vol. 2 No. 2 Juli 2020

DOI:https://doi.org/10.21009/Communications.2.2.1

\section{METODE PENELITIAN}

Pendekatan kualitatif dengan metode studi kasus digunakan dalam penelitian ini. Kasus yang diteliti dibatasi oleh waktu dan aktifitas. Peneliti melakukan kegiatan mulai dari mengumpulkan data dan informasi secara lengkap dengan menggunakan berbagai prosedur pengumpulan data berdasarkan waktu yang telah ditentukan (Creswell, 2010).

Teknik pengumpulan data dalam suatu penelitian dapat berupa data primer dan data sekunder. Peneliti menggunakan teknik pengumpulan data melalui dokumentasi dan studi yang ada. Penelitian ini berpedoman kepada proses analisa data yang pertama kali diperkenalkan oleh Miles dan Hubberman (Bungin, 2011).

Proses tahapan menganalisis data itu dimulai dengan mereduksi data (data reduction) atau membuang data yang tidak perlu, dilanjutkan dengan penyajian data (data display), kemudian penarikan kesimpulan (conclusion drawing) dan verifikasi data (verification). Adapun aspek ketergantungan merupakan versi kualitatif dari relialitas, hal tersebut dapat dicapai dengan melakukan audit atau pemeriksaan terhadap keseluruhan proses serta tahapan pada penelitian (Daymon \& Holloway, 2007).

Dalam penelitian ini, konsep yang digunakan Peneliti adalah performa komunikatif untuk bisa menangkap dan membaca fenomena bagaimana pemerintah melakukan sosialisasi kebijakan publik amnesti pajak. Performa komunikatif merupakan turunan dari teori budaya organisasi, dimana budaya organisasi menjadi esensi dari kehidupan berorganisasi.

Performa komunikatif merupakan istilah yang dimunculkan pertama kali oleh Pacanowsky dan O'Donnell (West \& Turner, 2008). Kedua ilmuwan tersebut menyatakan bahwa anggota organisasi melakukan performa komunikasi tertentu yang berakibat dengan munculnya budaya organisasi yang unik dan khusus. Adapun 
Communications Vol. 2 No. 2 Juli 2020

DOI:https://doi.org/10.21009/Communications.2.2.1

keunikan performa atau performance adalah metafora yang menggambarkan proses simbolik dari pemahaman dari perilaku manusia dalam sebuah organisasi.

Gambaran performa komunikatif pemerintah dalam sosialisasi kebijakan publik amnesti pajak menjadi fokus dalam penelitian. Sosialisasi dengan kata lain adalah transfer knowledge, bagaimana lewat proses pembelajaran suatu pengetahuan dipindahkan menjadi milik orang lain juga, dari seseorang kepada yang lain, dari pihak tertentu kepada pihak lain.

\section{HASIL DAN PEMBAHASAN}

Dit. P2 Humas Ditjen Pajak memiliki peran besar dalam sosalisasi kebijakan publik amnesti pajak sehubungan dengan tugas pokoknya merumuskan serta melaksanakan kebijakan dan standardisasi teknis di bidang penyuluhan, pelayanan dan hubungan masyarakat. Institusi pemerintah ini membuat berbagai strategi secara teknis untuk melakukan sosialisasi apalagi pelaksanaan kebijakan amnesti pajak sudah ditentukan waktunya hanya sembilan bulan saja. Selain Dit. P2Humas Ditjen Pajak berperan sangat besar dalam sosialisasi amnesti pajak di samping Presiden Jokowi sebagai kepala pemerintahan yang memegang peran penting juga terlibat dalam sosialisasi.

Hasil penelitian ini mendapatkan bagaimana performa komunikatif sosialisasi kebijakan amnesti pajak era pemerintahan Presiden Jokowi. Performa komunikatif adalah sebuah konsep dari teori budaya organisasi. Konsep ini yang memandu rangkaian penelitian yang dilakukan oleh Peneliti untuk menggali dan memperoleh data. Data diperoleh dari para narasumber serta menangkap dan mengungkap fenomena tentang performa sosialisasi kebijakan publik amnesti pajak pada pemerintahan Presiden Jokowi. Dalam pemaparan berikut, dapat dilihat performa komunikatif yang terdiri dari lima bagian yaitu performa ritual, performa hasrat, performa sosial, performa politis dan performa enkulturasi. 
Tidak dapat dipungkiri pada saat awal peluncuran kebijakan publi amnesti pajak ada kelemahan dalam mengomunikasikan kebijakan tersebut. Kelemahan dalam mengomunikasikan kebijakan publik itu yang menyebabkan kesimpangsiuran berita tentang amnesti pajak. Terdapat banyak pihak yang meragukan, muncul banyak polemik yang terjadi dalam masyarakat, adanya ketidaksepahaman, adanya penolakan, multi tafsir amnesti pajak terjadi di antara masyarakat bahkan ironisnya di antara pegawai Ditjen Pajak itu sendiri.

Ketidakpastian informasi di awal peluncuran kebijakan pengampunan pajak membuahkan keresahan masyarakat yang tercermin dalam percakapan sehari-hari atau percakapan di media sosial. Terjadi beberapa kesalahan persepsi yang timbul dimasyarakat antara lain publik menganggap bahwa tax amnesty mencederai rasa keadilan bagi wajib pajak yang patuh. Pemahaman yang keliru bahwa sasaran tax amnesty adalah hanya dana diluar negeri saja, bukan harta dalam negeri. Kekeliruan lain menyebutkan bahwa tax amnesty adalah kewajiban yang menindas rakyat kecil dan dinilai mengampuni koruptor dan penjahat. Sempat muncul istilah tax amnesty merupakan "jebakan batman" bagi wajib pajak. Ada juga pendapat yang mengatakan bahwa pengampunan pajak menguntungkan dan keberpihakan pemerintah terhadap orang kaya.

Komunikasi kebijakan publik amnesti pajak dilakukan dalam sosialisasi secara komprehensif, terkoordinasi dan terintegrasi oleh pemerintah. Presiden, Kementerian Keuangan dan Direktorat Jenderal Pajak serta kerjasama antar institusi pemerintah dan lembaga lainnya. Semua daya upaya dilakukan mengingat sosialisasi dan implementasi kebijakan amnesti pajak dilaksanakan dalam waktu yang bersamaan serta dalam waktu yang singkat pula.

Tiada jeda antara sosialisasi dan implementasi, itu pun merupakan kesulitan tersendiri. Semuanya harus dilaksanakan dalam kurun waktu yang bersamaan dan cukup singkat sembilan bulan. Kurun waktu sembilan bulan yang begitu singkat itu 
menjadi extra effort bagi Ditjen Pajak, ke dalam harus cepat membangun capacity building seluruh pegawai pajak tentang konten Amnesti Pajak, ke luar harus segera memberikan sosialisasi kepada seluruh masyarakat. Tujuannya agar masyarakat mengetahui dan memakai haknya untuk ikut program amnesti pajak.

Pelaksanaan amnesti pajak dalam kurun waktu tiga periode selama sembilan bulan yaitu mulai 1 Juli 2016 dan berakhir 31 Maret 2017 dengan pembagian tiga periode sebagai berikut: Periode 1 Juli 2016 sampai dengan 30 September 2016, Periode 2 tanggal 1 Oktober sampai dengan 31 Desember 2016, dan Periode 3 tanggal 1 Januari sampai dengan 31 Maret 2017.

Sosialisasi dilakukan dengan berbagai strategi baik internal maupun eksternal Ditjen Pajak. Informasi tentang pengampunan pajak pun telah tersebar secara masif melalui media elektronik, media cetak, media online, media sosial, telepon layanan, helpdesk dan lain sebagainya.

Sosialisasi kebijakan amnesti pajak berjalan selama sembilan bulan bersamaan dengan pelaksanaan kebijakan itu sendiri. Sosialisasi merupakan faktor utama atau motor dalam menggerakkan tax amnesty. Walaupun sosialisasi dan implementasi bersamaan waktunya dimana sosialisasi harus dilakukan secara maraton tapi dapat menghasilkan sisi positif. Sisi positif yaitu menghasilkan 11.800 sosialisasi yang diselenggarakan di seluruh Indonesia. Presiden, Menteri, Dirjen, Kantor Pusat, Kantor Wilayah (Kanwil), Kantor Pelayanan Pajak (KPP), Kantor Pelayanan, Penyuluhan dan Konsultasi Perpajakan (KP2KP), semua terlibat sosialisasi (RYNDANG SRIGANDA, 2017) .

Sosialisasi yang dilakukan secara optimal dengan melibatkan Presiden dan para pejabat sesuai kapasitasnya serta pegawai pajak, tetapi hasilnya tidak terlalu maksimal dan signifikan. Hasil amnesti pajak masih kurang memuaskan jika dikaitkan dengan jumlah wajib pajak yang ikut amnesti dan jumlah uang tebusan 
yang diperoleh. Hasil dari amnesti pajak menunjukkan 972.530 wajib pajak yang ikut amnesti pajak dan tebusannya berjumlah 135 triliun rupiah. Uang tebusan yang terkumpul masih di bawah target yang diharapkan seharusnya sebesar 165 triliun rupiah.

Tabel di bawah ini menunjukkan negara-negara yang pernah melakukan program amnesti pajak, jumlah uang tebusan yang diperoleh negara Indonesia merupakan tertinggi di dunia, jumlah deklarasi harta repatriasi, deklarasi dalam negeri, deklarasi luar negeri, jumlah peserta yang ikut amnesti pajak. Indonesia termasuk negara yang memperoleh jumlah tebusan yang paling tinggi.

Tabel 2

Tebusan Amnesti Pajak Indonesia Terbesar di Dunia:

\begin{tabular}{|c|c|c|}
\hline No. & Negara & $\begin{array}{c}\text { Jumlah Tebusan } \\
\text { (Dalam Triliun Rupiah) }\end{array}$ \\
\hline 1. & India (1997) & 1,4 \\
\hline 2. & Afrika Selatan (2003) & 2,8 \\
\hline 3. & Belgia (2004) & 5,9 \\
\hline 4. & Jerman (2204) & 11,3 \\
\hline 5. & Italia (2009) & 54,2 \\
\hline 6. & Spanyol (2012) & 15,5 \\
\hline 7. & Australia (2014) & 7,4 \\
\hline 8. & Chile (2015) & 135 \\
\hline 9. & Indonesia (2016) & 20,7 \\
\hline
\end{tabular}

Sumber: (RYNDANG SRIGANDA, 2017)

Tabel 3

Deklarasi Harta

\begin{tabular}{|c|c|}
\hline Deklarasi & $\begin{array}{c}\text { Jumlah } \\
\text { (Dalam Triliun Rupiah) }\end{array}$ \\
\hline Repatriasi & 147 \\
\hline
\end{tabular}


Communications Vol. 2 No. 2 Juli 2020

DOI:https://doi.org/10.21009/Communications.2.2.1

\begin{tabular}{|c|c|}
\hline Deklarasi Luar Negeri & 1036 \\
\hline Deklarasi Dalam negeri & 3698 \\
\hline Total & 4881 \\
\hline
\end{tabular}

Sumber: (RYNDANG SRIGANDA, 2017)

Tabel 4

Jumlah Peserta Wajib Pajak

\begin{tabular}{|l|c|}
\hline \multicolumn{1}{|c|}{ Peserta } & Jumlah \\
\cline { 1 - 1 } Wajib Pajak Orang Pribadi Non Usaha Mikro Kecil dan & \\
Menengah & $\begin{array}{c}\text { Termasuk } \\
52.757 \text { WP }\end{array}$ \\
\cline { 1 - 1 } Wajib Pajak Orang Pribadi Usaha Mikro Kecil dan Menengah \\
\cline { 1 - 1 } Wajib Pajak Badan Non Usaha Mikro Kecil dan Menengah & \\
\cline { 1 - 1 } Wajib Pajak Badan Usaha Mikro Kecil dan Menengah & \\
\hline
\end{tabular}

Sumber: (RYNDANG SRIGANDA, 2017)

Performa komunikatif pemerintah dalam melakukan sosialisasi kebijakan amnesti pajak oleh Dit. P2Humas Ditjen Pajak pada masa pemerintahan Presiden Jokowi dipaparkan dalam hasil penelitian ini. Hasil pembahasan menunjukkan bagaimana keterlibatan Presiden Jokowi, para pejabat dan pegawai pajak serta koordinasi dengan institusi pemerintah dan antar lembaga lainnya. Dalam pemaparan berikut, dapat dilihat performa komunikatif yang terdiri dari lima bagian yaitu performa ritual, performa hasrat, performa sosial, performa politis dan performa enkulturasi.

\section{Performa Ritual.}

Seluruh performa sosialisasi amnesti pajak dilakukan secara teratur dan berulang, performa ritual yang terdiri dari empat bagian yaitu ritual personal, ritual tugas, ritual sosial dan ritual organisasi yang dilakukan oleh Presiden Jokowi, Kementerian Keuangan dan Direktorat Jenderal Pajak. 
Communications Vol. 2 No. 2 Juli 2020

DOI:https://doi.org/10.21009/Communications.2.2.1

\section{Ritual Personal.}

Keterlibatan Presiden Jokowi dalam ritual personalnya pada sosialisasi amnesti pajak dimulai saat mencanangkan program kebijakan amnesti pajak pada tanggal 1 Juli 2016 di Auditorium Cakti Buddhi Bhakti Kantor Pusat Direktorat Jenderal Pajak. Dalam sambutannya, Presiden Jokowi mengajak para peserta yang hadir pada acara pencanangan tersebut untuk ikut dan mendukung tax amnesty. Bagaimana pentingnya keterlibatan sosok personal Presiden Jokowi dalam sosialisasi sudah diperkirakan oleh Ditjen Pajak, oleh sebab itu di awal perencanaan sosialisasi telah diusulkan Presiden yang menjadi modelnya.

Ditjen Pajak merasa tokoh siapa pun baik dari kalangan pengusaha atau artis tidak cukup untuk menjadi model amnesti pajak. Mengingat itu semua pilihan jatuh kepada Presiden Jokowi demikian diungkap oleh Hestu Yoga Saksama. Dalam kegiatan Presiden Jokowi dalam melakukan sosialisasi Amnesti Pajak menunjukkan kehadiran peserta sosialisasi yang terbilang sangat banyak. Masyarakat antusias hadir dalam setiap sosialisasi yang dihadiri Presiden. Hal itu juga menunjukkan Presiden sebagai model dan tokoh yang sangat tepat dalam melakukan sosialisasi.

Dit. P2Humas Ditjen Pajak dalam beberapa perencanaan sosialisasi dalam skala besar mengagendakan kehadiran Presiden. Di samping itu kehadiran Menteri Keuangan, Dirjen Pajak, Pejabat Negara juga masuk dalam berbagai agenda sosialisasi. Terlihat dalam melakukan ritual tugas sosialisasi, Presiden Jokowi melakukannya di beberapa kota besar bersama Menteri Keuangan Sri Mulyani Indrawati, Dirjen Pajak saat itu Ken Dwijugiasteadi. Dalam setiap periode, Presiden selalu dijadwalkan sosialisasi seperti data terlampir dalam tabel 5 dibawah ini menunjukkan kekonsistenan Jokowi dalam mengawal amnesti pajak. 
Communications Vol. 2 No. 2 Juli 2020

DOI:https://doi.org/10.21009/Communications.2.2.1

Tabel 5

Kegiatan Presiden Jokowi Sosialisasi Amnesti Pajak di Kota-kota Besar

\begin{tabular}{|c|c|c|c|c|}
\hline No. & Tanggal & Acara & Tempat & Peserta \\
\hline 1. & 1 Juli 2016 & Peluncuran Amnesti Pajak & Kantor Pusat Ditjen Pajak & 600 \\
\hline 2. & 15 Juli 2016 & Sosialisasi Amnesti Pajak & Grand City Surabaya & 1000 \\
\hline 3. & 21 Juli 2016 & Sosialisasi Amnesti Pajak & Hotel Santika Medan & 1000 \\
\hline 4. & 8 Agustus 2016 & Sosialisasi Amnesti Pajak & $\begin{array}{l}\text { Hotel Intercontinental } \\
\text { Bandung }\end{array}$ & 4000 \\
\hline 5. & $\begin{array}{l}25 \text { November } \\
2016\end{array}$ & Dialog Perpajakan & $\begin{array}{l}\text { Hotel Grand Clarion, } \\
\text { Makassar }\end{array}$ & 4000 \\
\hline 6. & $\begin{array}{l}28 \text { November } \\
2016\end{array}$ & Dialog Perpajakan & $\begin{array}{l}\text { Hall Platinum Balikpapan } \\
\text { Hotel }\end{array}$ & 1000 \\
\hline 7. & $\begin{array}{l}30 \text { November } \\
2016\end{array}$ & Dialog Perpajakan & $\begin{array}{l}\text { Bali Nusa Dua Convention } \\
\text { Centre }\end{array}$ & 1000 \\
\hline 8. & $\begin{array}{l}9 \text { Desember } \\
2016\end{array}$ & Dialog Perpajakan & Istana Negara & 300 \\
\hline 9. & $\begin{array}{l}28 \text { Februari } \\
2017\end{array}$ & Farewell Amnesti Pajak & $\begin{array}{l}\text { JIEXpo Kemayoran Jakarta } \\
\text { Pusat }\end{array}$ & 14000 \\
\hline
\end{tabular}

Sumber: (RYNDANG SRIGANDA, 2017)

Presiden melakukan sosialisasi di hadapan kurang lebih 2010 pelaku usaha dari Bali dan Nusa Tenggara yang hadir di Bali Nusa Dua Convention Center (BNDCC), Jokowi menekankan bahwa amnesti pajak ini merupakan program yang terakhir. Terakhir yang dimaksud Presiden adalah program besar di bidang perpajakan sebelum era keterbukaan informasi diberlakukan pada 2018. Presiden Jokowi mengingatkan agar kebijakan amnesti pajak dapat dimanfaatkan dengan sebaikbaiknya. 
Beberapa kutipan pernyataan Presiden Jokowi pada acara yang dilaksanakan di Bali pada tanggal 8 Desember 2016 bahwa Jokowi mengajak para wajib pajak untuk berpartisipasi menggunakan manfaat amnesti pajak. Bahkan dikatakan Presiden sengaja datang menggunakan pakaian lengkap sipil atau jas untuk memberi penyadaran. Khusus sosialisasi kepada wajib pajak di BNDCC penampilannya agak berbeda di mana biasanya Jokowi memakai kemeja putih dalam bekerja serta blusukan ke daerah-daerah keluar masuk kampung atau desa.

Dalam kesempatan itu, Presiden menyerukan pentingnya partisipasi masyarakat untuk menyukseskan program tax amnesty, oleh karena itu beliau menyatakan turun sendiri untuk memberikan penyadaran kepada masyarakat. Dana amnesti yang terkumpul penting untuk penerimaan negara dan dapat dimanfaatkan untuk pembangunan di berbagai sektor.

Disampaikan bahwa nusantara ini, dari Sabang sampai Merauke butuh dana yang besar untuk membangun infrastruktur, sektor pendidikan, sektor kesehatan dan seluruh sendi kehidupan yang bermanfaat untuk hajat hidup masyarakat. Ditambahkan Presiden, sungguh berbahagia jika kita sebagai bangsa Indonesia memiliki kemampuan sendiri untuk membangun negeri tercinta ini. Indonesia dapat mandiri dalam dalam dana. Menjadi suatu kebanggaan Indonesia menjadi bangsa yang besar yang dapat berdiri di atas kakinya sendiri. Dalam rangka berproses menjadi mandiri, bertahap untuk dapat berdiri di atas kaki sendiri, pemerintah membuat salah satu kebijakan publik yaitu tax amnesty.

\section{Ritual Sosial.}

Dalam ritual sosial yang meliputi rutinitas sosialisasi verbal dan nonverbal dilakukan oleh Direktorat Jenderal Pajak dalam hubungannya dengan kegiatan konsisten berulang-ulang di antar pegawai mulai dari Kantor Pusat, Kanwil, KPP dan KP2KP. Untuk mengakomodir kegiatan rutinitas yang dilakukan dalam rangka mengeksekusi kebijakan Amnesti Pajak, maka salah satu jalannya adalah membuat Sekretariat Bersama, di mana penyuluhan atau sosialisasi akan berasal dari satu pintu 
Communications Vol. 2 No. 2 Juli 2020

DOI:https://doi.org/10.21009/Communications.2.2.1

pengelolaannya. Komitmen pegawai pajak dibuktikan bahwa mereka dengan sepenuh hati melakukan tugas mengimplementasikan kebijakan amnesti tersebut, mereka berdiri paling depan, bekerja dengan sungguh-sungguh.

\section{Ritual Organisasi}

Dalam ritual yang organisasi melikupi cakupan yang luas yang diselenggarakan secara kebih luas dalam sebuah organisasi, dalam hal ini antara Direktorat Jenderal Pajak, Kementerian Keuangan dan Kantor Staf Presiden. Sosialisasi Amnesti Pajak menyangkut hal-hal yang dilakukan dalam kegiatan organisasi yang mendukung pelaksanan sosialisasi.

Di level Kementerian Keuangan, ikut turun mengarahkan strategi adalah Menteri Keuangan. Dalam beberapa kesempatan para stakeholder semua unit eselon satu di lingkungan Kementerian Keuangan diundang untuk ikut hadir dalam sosialiasi. Kerjasama birokrasi semuat unit eselon satu di bawah Kementerian Keuangan Kementerian berjalan secara sinergis dan terkoordinir dengan baik. Begitu pun dalam hal sosialisasi, Kementerian Keuangan membantu ikut menyosialisasikan pada semua media sosial yang dimiliki, sedangkan pembuatan gran narasi yang membuat adalah Dit. P2Humas Ditjen Pajak sehingga konten dan isi narasi berisi pesan yang sama.

Dalam sosialisasi, Kementerian Keuangan memberi support dengan menggunakan media yang ada di lingkungan Kementerian Keuangan. Liputan kegiatan amnesti pajak ditayangkan pada portal Kementerian Keuangan dan media sosial. Sdapaun media sosial yang dikelola Kementerian Keuangan yaitu Facebook, Twitter, Instagram, digital media yang lain. 
Gambar 1

Infografis dan Gran Narasi

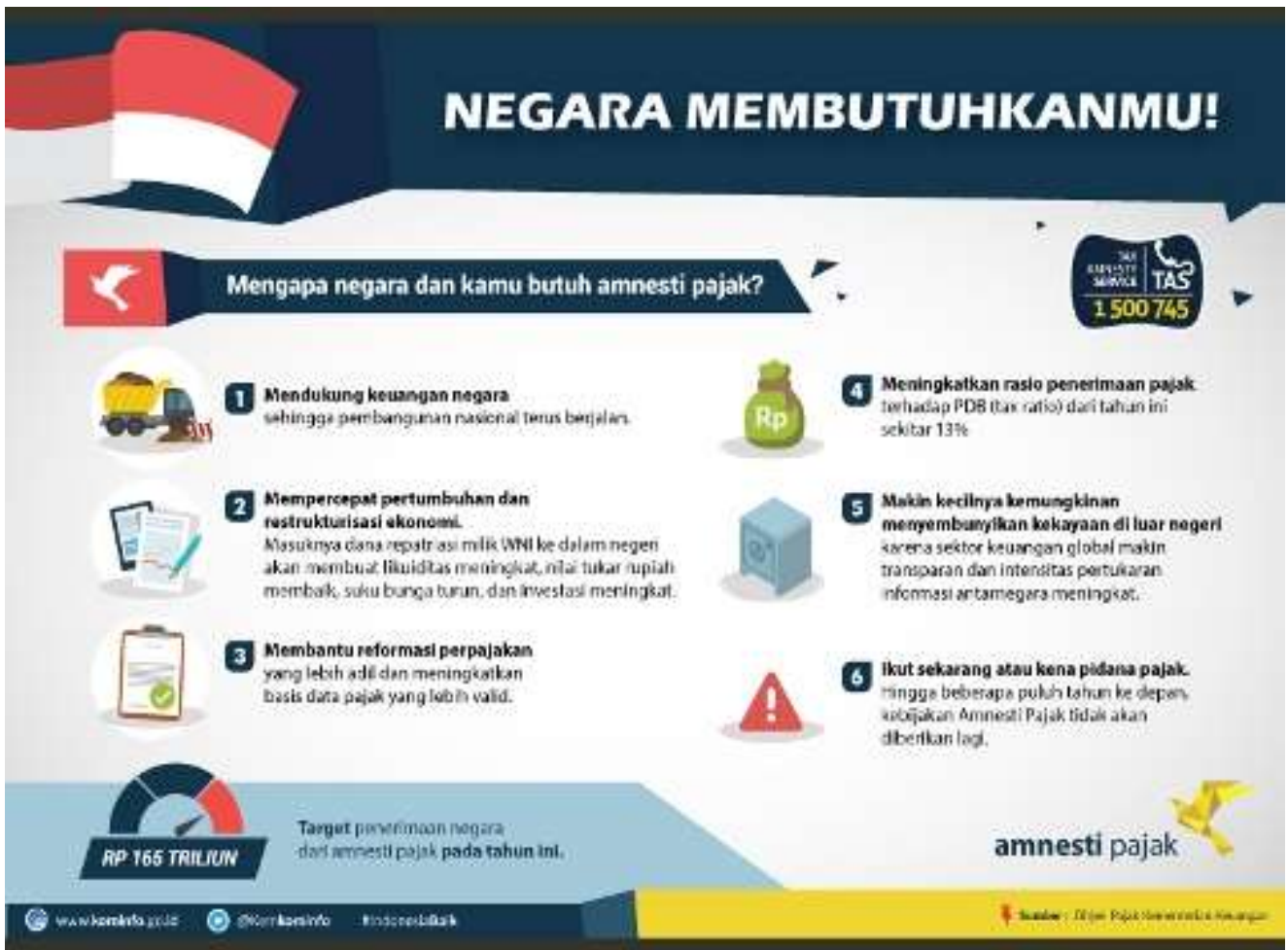

Sumber: (RYNDANG SRIGANDA, 2017)

Gran narasi dibuat oleh Dit. P2Humas, lalu oleh Kementerian Keuangan disampaikan kepada Kementerian Komunikasi dan Informasi selanjutnya disebarkan kepada seluruh Kementerian. Dengan gran narasi yang dibuat dalam satu pintu diharapkan semua pihak mendapatkan sosialisasi dan informasi tentang konten yang sama

\section{Performa Hasrat}

Hasrat di sini menggambarkan keinginan berbagi atau sharing atau curhat (curahan hati) di antara para pegawai Ditjen Pajak mengenai kondisi internal Direktorat Jenderal Pajak ketika kebijakan amnesti pajak berlangsung. Performa hasrat itu dimulai ketika kebijakan dimulai, apakah ada keinginan para pegawai untuk mempelajarinya atau melakukan extra effort. Pegawai mau dijadwalkan lembur, hari Sabtu-Minggu pun siap dijadwalkan untuk piket bekerja. 
Communications Vol. 2 No. 2 Juli 2020

DOI:https://doi.org/10.21009/Communications.2.2.1

\section{Performa Sosial}

Performa sosial di sini menunjukkan sikap sopan santun di antara pegawai Ditjen Pajak dalam berkomunikasi tentang amnesti pajak memakai simbol atau tanda yang sudah dikenali. Pegawai Ditjen Pajak sering diundang menjadi narasumber oleh berbagai acara sosialisasi. Banyak peserta sosialisasi menginginkan kehadiran langsung Dirjen Pajak sebagai narasumber. Untuk mengatasi persoalan itu diatur siapa yang akan menjadi narasumber dengan memperhatikan sisi psikologis dari peserta sosialisasi.

Para narasumber dalam sosialisasi juga ada strata atau tingkatannya, dibagi untuk kebutuhan khusus agar tepat guna, efisien dan efektif. Bukan hanya di level pejabat saja yang dapat menjadi narasumber atau trainer, di tataran pelaksana juga dapat menjadi narasumber. Secara khusus di KPP mereka berperan di bagian pelayanan dan petugas helpdesk melayani pertanyaan dari pegawai pajak, menuntun para wajib pajak melakukan amnesti pajak, mereka berdiri paling depan.

\section{Performa Politis}

Struktur dan hirarki dalam pemerintahan Negara Kesatuan Republik Indonesia pemegang kepala pemerintahan tertinggi adalah Presiden dibantu oleh para Menteri, di mana setiap Menteri memimpin sebuah Kementerian. Demikian pula dengan Kementerian Keuangan dipimpin oleh seorang Menteri, di bawahnya ada beberapa direktorat teknis, diantaranya Direktorat Jenderal Pajak. Presiden menjalankan fungsi kekuasaan dan kontrol terhadap Kementerian dan Ditjen Pajak dalam mengimplementasikan amnesti pajak.

Dalam sambutan Presiden Jokowi disampaikan tentang latar belakang serta tujuan lahirnya amnesti pajak pada saat mencanangkan program kebijakan Amnesti Pajak pada tanggal 1 Juli 2016. Presiden mengatakan bahwa amnesti pajak adalah sebuah terobosan agar masalah-masalah perpajakan dapat terselesaikan. Ekspektasinya yaitu hasilnya bermanfaat untuk kepentingan bangsa dan rakyat Indonesia. 
Communications Vol. 2 No. 2 Juli 2020

DOI:https://doi.org/10.21009/Communications.2.2.1

\section{Performa Enkulturasi}

Dalam menyosialisasikan kebijakan amnesti pajak, sebagai direktorat teknis maka Ditjen Pajak harus menambah kompetensi para pegawainya dengan membangun dan meningkatkan kapasitasnya (capacity building). Sosialisasi erat sekali kaitannya dengan enkulturasi yang merujuk pada bagaimana anggota mendapatkan pengetahuan dan keahlian. Pegawai yang sudah mendapat pengetahuan amnesti pajak dapat menjadi narasumber dalam berbagai sosialisasi di mana pun dan kapan pun sudah siap sedia.

Pertama-tama sosialisasi tentang konten amnesti pajak yang disasar adalah para pegawai Ditjen Pajak dengan alasan sebelum sosialisasi ke eksternal Ditjen Pajak. Pegawai pajak harus mengerti terlebih dahulu tentang pemahaman mendalam soal amnesti pajak. Sosialisasi internal pun dilakukan dengan keseriusan dan penuh strategi dalam rangka pengayaan pengetahuan.

Dengan kata lain pegawai pajak menjadi agen sosialisasi atau menjadi narasumber untuk sosialisasi kepada pihak eksternal. Dit. P2Humas Ditjen Pajak sangat konsen dalam melakukan penguatan dan pemahaman terhadap konten amnesti pajak. Bimbingan teknis (bimtek) adalah salah satu cara membangun capacity building. Selanjutnya sosialisasi eksternal dilakukan secara struktural pemerintahan oleh Presiden, Menteri, Dirjen Pajak dan para pegawai yang sudah mendapatkan capacity building melalui sosialisasi internal. Sosialisasi eksternal dilakukan dilakukan untuk seluruh masyarakat baik wajib pajak maupun non wajib pajak. Semuanya menyasar masyarakat yang sudah menjadi wajib pajak ataupun yang belum menjadi wajib pajak.

Seluruh rangkaian sosialisasi diakhiri dengan berakhirnya pula pelaksanaan amnesti pajak Dir. P2Humas Ditjen Pajak mengatakan bahwa jajaran Ditjen Pajak mulai dari Kantor Pusat, Kanwil, KPP, KP2KP untuk menjaga kualitas sosialisasi amnesti pajak. Hasil positif kerja extra effort para pegawai pajak terselenggara 11.800 sosialisasi yang 
Communications Vol. 2 No. 2 Juli 2020

DOI:https://doi.org/10.21009/Communications.2.2.1

sudah dilakukan di seluruh Indonesia selama kurun waktu kurang lebih sembilan bulan.

\section{KESIMPULAN}

Berdasarkan uraian yang telah Penulis jelaskan di atas maka dapat disimpulkan bahwa sosialisasi kebijakan publik amnesti pajak oleh pemerintah telah dilakukan dengan terstruktur dan terencana oleh institusi pemerintah Dit. P2Humas Ditjen Pajak. Sosialisasi dilakukan untuk pihak internal maupun eksternal lingkungan Dit. P2Humas Ditjen Pajak. Sosialisasi amnesti pajak melibatkan pemimpin tertinggi pemerintahan Presiden Joko Widodo. Sosialisasi internal sangat urgen dan lebih dahulu dilakukan sebelum sosialisasi eksternal disebabkan semua pegawai pajak adalah narasumber kebijakan amnesti pajak. Hasil dari sosialisasi amnesti pajak yang dilakukan pemerintah adalah masyarakat Indonesia mendapatkan pengetahuan tentang amnesti pajak. Walaupun sudah dilakukan sosialisasi dengan berbagai upaya, hasil dari amnesti pajak tidak sesuai target dengan kata lain hasilnya di bawah target yang diharapkan. Untuk itu disarankan agar dilakukan penelitian di kemudian hari mengenai hubungan sosialisasi dengan tingkat kepatuhan dan ketaatan masyarakat terhadap suatu kebijakan publik.

\section{DAFTAR PUSTAKA}

\section{Book}

Creswell, J. W. (2010). Research design pendekatan kualitatif, kuantitatif, dan mixed. Yogyakarta: Pustaka Pelajar.

Daymon, C., \& Holloway, I. (2007). Metode-metode riset kualitatif dalam public relations dan marketing communications. Yogyakarta: Bentang Pustaka.

Kamanto, S. (2004). Pengantar sosiologi. Jakarta: Lembaga Penerbit Fakultas Ekonomi Universitas Indonesia

West, R., \& Turner, L. H. (2008). Pengantar teori komunikasi: analisis dan aplikasi. Jakarta: Salemba Humanika. 
Communications Vol. 2 No. 2 Juli 2020

DOI:https://doi.org/10.21009/Communications.2.2.1

\section{Journal Articles}

Ngadiman, N., \& Huslin, D. (2015). Pengaruh Sunset Policy, Tax Amnesty, Dan Sanksi Pajak Terhadap Kepatuhan Wajib Pajak (Studi Empiris Di Kantor Pelayanan Pajak Pratama Jakarta Kembangan). Jurnal Akuntansi, 19(2), 225-241.

Putri, R. (2017). Pemberlakuan Tax Amnesty Berdasarkan UU Nomor 11 Tahun 2016 Tentang Pengampunan Pajak. Lex Privatum, 5(4).

Rumata, V. M. (2017). Analisis Isi Kualitatif Twitter “\#TaxAmnesty” dan “\#AmnestiPajak.” Jurnal Penelitian Komunikasi Dan Pembangunan, 18(1), 1. https:/ / doi.org/10.31346/jpkp.v18i1.840

Ryndang Sriganda, M. L. D. (2017). Komunikasi Kebijakan Publik Amnesti Pajak:

Pemodelan Sosialisasi Kebijakan Era Pemerintahan Presiden Joko Widodo. universitas mercu buana.

Tanilasari, Y., \& Gunarso, P. (2017). Analisis Pengaruh Kesadaran Wajib Pajak Dan Kualitas Pelayanan Fiskus Terhadap Kepatuhan Wajib Pajak Orang Pribadi Pada Kantor Pelayanan Pajak Pratama Malang Selatan. Jurnal Akuntansi Dan Perpajakan, 3(1), 1-9. https:// doi.org/10.26905/ap.v3i1.1324

Wijaya, Z. S. (2015). Penerapan Sistem Informasi Berbasis Komputer Pada Aplikasi Monitoring Keuangan Dan Aset ( Terkait Penatausahaan Piutang Tuntutan Ganti Kerugian Negara ). Jurnal Ekonomi Akutansi Dan Manajemen, 14(1), 1-10. 